\title{
単一槽高負荷脱窒素反応器のモデル化と 操作因子に関する研究
}

\section{津野 洋*・宗宮 功**.山田登志夫***. 西村文武****}

本研究では良好な処理成績で運転されている単一槽高負荷脱窒素システムについて処 理特性をシミュレートしうる数理モデルを作成した. モデルは反応槽を無酸素ゾーンお よび好気性ゾーン ( 2 区画) に分け, 各々の区画につき有機物除去および硝化・脱窒な らびにこれらに関与する微生物増殖を組み込んだ詳細なものである.この数理モデルの 検証を行うとともに, 操作因子について検討を行い, その結果 HRT が 4.5 日で中区画 での DO 濃度が $1 \mathrm{mg} / l$ 程度で運転されることが, 処理性および安定性から適切である ことを示した。

Key Words : mathematical model, single high-loaded denitrification reactor, night soil treatment, removal of organic matter, nitrification, denitrification

\section{1.はじめに}

湖沼や内湾などの富栄養化防止，水道水源や農業用水 源の保全などのために，し尿処理においても有機物のみ ならず窒素の除去が必要かつ重要となり，生物学的硝 化・脱窒法が活用されている. し尿処理においては，有 機物が高濃度であることから, 反応槽内に局部的な嫌気 性ゾーンや好気性ゾーンを出現させやすく, 有機物除去, 硝化および脱窒の各反応を並行して生じさせうることが 知られており，これを活用したし尿処理法か開発されて (る ${ }^{1,2)}$. これらの中で, 単一槽高負荷脱窒素反応器では, 同一生物反応槽内に好気性ゾーンと無酸素ゾーンを確実 に形成させ，かつ大量の水を循環して疑似完全混合状態 を作り出すことにより, 従来の硝化・脱窒処理法では 2 槽の反応槽を使用していた欠点を克服するとともに高率 の有機物除去之窒素除去を行わしめている. しかしなが ら, その反応器の中で生じている各種機構については定 量的に把握されておらず, 設計・操作は経験に基づいて いる状況である.

本研究では, 単一槽高負荷脱窒素反応器で生じている 反応機構のモデル化を行い, 効率よく有機物および窒素 の処理が行われているし尿処理場における処理特性把握 の調査によりモデルの検証を試みるとともに，その数理 モデルを用いて操作因子の検討を試みた.この数理モデ ルは, 有機物除去, 硝化, 脱窒および関連微生物の増殖 の各過程が組み込まれたものである。これらの各過程は 下水処理の分野では各々別個にモデル化され検討されて いる ${ }^{3)}$ が，すべての過程の相互関連も含めて結合し，し 尿処理反応器中の反応機構を組み込んだ詳細なモデルは

\footnotetext{
*正会員 工博 京都大学助教授 工学部衛生工学科 ( 邓606-01 京都市左京区吉田本町)

** 正会員 工博 京都大学教授 工学部衛生工学科

*** 正会員 工博 アタ力工業 (株) 技術研究所

**** 学生会員 工修 京都大学大学院工学研究科
}

見当たらない．またし尿という高濃度のものを対象にす ることから各反応の影響が敏感であり，これらの各過程 の相互関連を表現しうるモデルは，モデルの開発の観点 からも意義のあるものと考えられる.

\section{2. し尿処理施設の概要}

本研究で対象にしたし尿処理場では, 生し尿と浄化槽 污泥が $7: 1$ の比で処理されている.このし尿・浄化槽 污泥（以下「し尿等」という）は，沈砂タンクで砂や金 属類が沈降分離され，また破砕ポンプ・細目スクリーン で夾雑物 (し查) が除去された後, 生物反応槽に投入さ れ，有機物分解および窒素除去（硝化・脱窒）がなされ る. 反応槽からの流出水は分離槽で貯留され, 一部は微 生物供給のために反応槽に返送され, 残りは脱水機にか けられ液と污泥に分離される.

その生物反応槽の概略を図一1に示す，反応槽は，容 積 $270 \mathrm{~m}^{3}$ で水深 $10.2 \mathrm{~m}$ の竪型であり, 底部より混合液 が頂部に大量に循環される構造となっている. また，循 環液とともに上部より空気が勢いよく噴射され（エジェ クター方式), それは上部約 $1 / 3$ のところまで到達し, その部分には好気性ゾーンが現出される.下部約 $1 / 3$ の 部分は上部の噴射流が直接到達しないようになってお り，また流入水（し尿等）をこの部分に流入せしめて, この部分は無酸素ゾーンが現出しうるようになってい る. 分離槽への引き抜きは反応槽の中部よりなされてい る. 分離槽加ら応槽への返送は, 沈殿污泥と浮上污泥 の両者でなされており, 前者は反応槽の底部に, また後 者は反応槽の上部になされている. なお, 分離槽の容積 は $60 \mathrm{~m}^{3}$ であるが，二つの生物反応槽で共通に用いられ ている.

反応槽へのし尿等の流入は間欠流入方式が採用されて おり，調查期間中では 60 分サイクルにセットされてい た。すなわち，し尿等の流入は初期の 23 分間でなされ， 


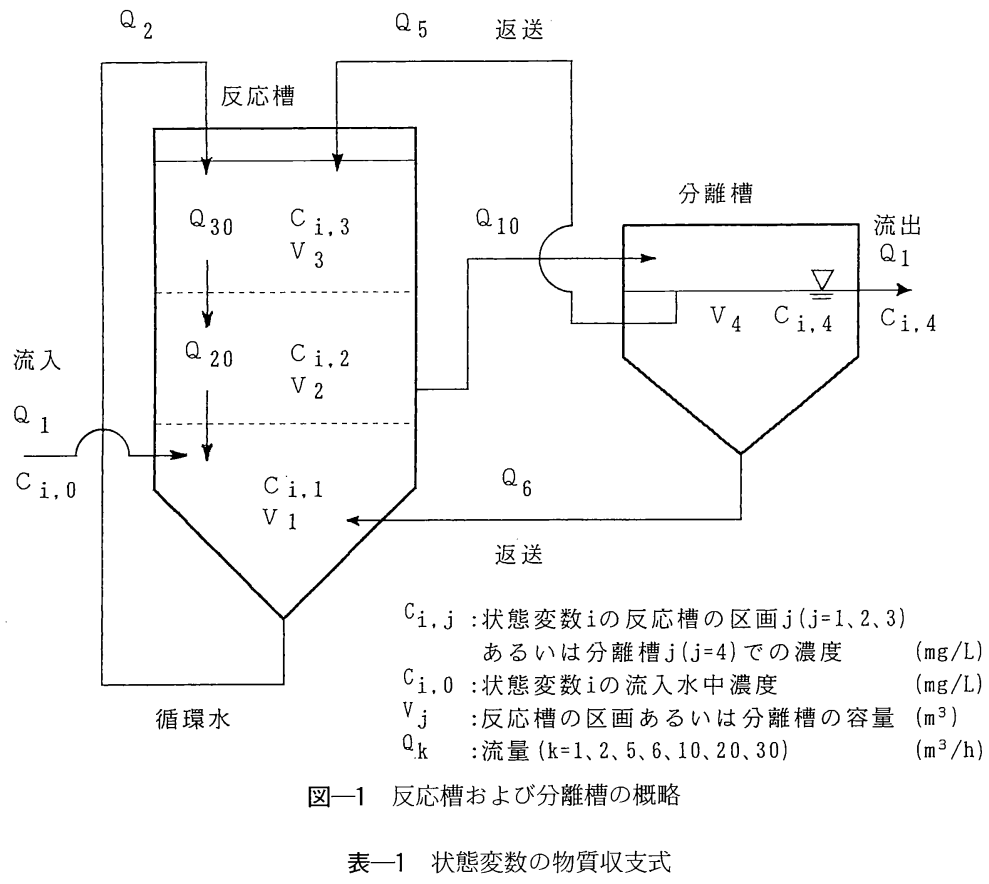

\begin{tabular}{|c|c|}
\hline $\begin{array}{l}\text { 反応槽区画 } 1 \\
\qquad V_{1} \frac{d}{d t}=Q_{1} C_{i}, 0+W_{1} Q_{6} C_{1,4}+Q_{20} C_{i, 2}-Q_{2} C_{i, 1}+V_{1} F_{i, 1}\end{array}$ & (4) \\
\hline $\begin{array}{l}\text { 反応槽区画 } 2 \\
\qquad V_{2} \frac{\mathrm{dC}_{\mathrm{i}, 2}}{\mathrm{dt}}=\mathrm{Q}_{30} \mathrm{C}_{\mathrm{i}, 3}-\mathrm{Q}_{20} \mathrm{C}_{\mathrm{i}, 2}-\mathrm{Q}_{10} \mathrm{C}_{\mathrm{i}, 2}+\mathrm{V}_{2} \mathrm{~F}_{1,2}\end{array}$ & (5) \\
\hline $\begin{array}{l}\text { 反応槽区画 } 3 \\
\qquad V_{3} \frac{\mathrm{dC}_{1,3}}{\mathrm{dt}}=\mathrm{Q}_{2} \mathrm{C}_{1,1}+\mathbb{W}_{2} \mathrm{Q}_{5} \mathrm{C}_{1,4}-\mathrm{Q}_{30} \mathrm{C}_{1,3}+\mathrm{V}_{3} \mathrm{~F}_{1,3}\end{array}$ & (6) \\
\hline 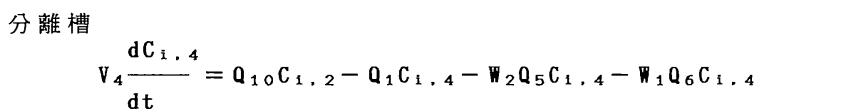 & (7) \\
\hline
\end{tabular}

$F_{i, j}$ : 反応槽区画 $\mathrm{j} て ゙ の$ 状態变数 $\mathrm{i}$ の生成速度

残りの 37 分間は流入を休止するというサイクルに設定 されていた１サイクルでのし尿等の流入量は，ほぼ一 定で $2.5 \mathrm{~m}^{3} / \mathrm{h}$ であった. この值を用いると, 反応槽内 の流入水量ベースでの水理学的滞留時間は 4.5 日とな る. 分離槽から反応槽への污泥返送は，調査期間中はほ ぼ一定であり, 沈殿污泥亡浮上污泥で各々 2.4 および $3.6 \mathrm{~m}^{3} / \mathrm{h}$ であった. これらを加味すると, 反応槽での 実質的な滞留時間は，1.3 日である. 反応槽への空気量 は， $1,100 \sim 1,300 \mathrm{~m}^{3} / \mathrm{h}$ の範囲であった．また槽内の混 合液の循環量は $27 \mathrm{~m}^{3}$ /分であり, 生物反応槽内での循 環は 10 分に 1 度となる.

\section{3. 数理モデル}

\section{（1）流動モデルと物質収支式}

反応槽は, その構造および想定操作条件より, 好気性 ゾーン, 微好気性ゾーンおよび無酸素ゾーンを設定しう るように三つの区画に分割する (図一1). 底部より頂部 に向かって区画 1,2 および 3 とし, その容積は各々 $V_{1}$ $=94 \mathrm{~m}^{3}$ および $V_{2}=V_{3}=88 \mathrm{~m}^{3}$ とする. そして, (1)反応 槽の各区画および分離槽では完全混合である，ならびに (2)各槽はオーバーフロー調節にて水容積の変化はなく, また各区画の容積も変化しないと仮定する．このような 仮定の下では，以下の水量収支式が成立する.

$$
\begin{aligned}
& Q_{10}=Q_{1}+Q_{5}+Q_{6} \cdots \\
& Q_{20}=Q_{2}+Q_{5}-Q_{10} \cdots
\end{aligned}
$$




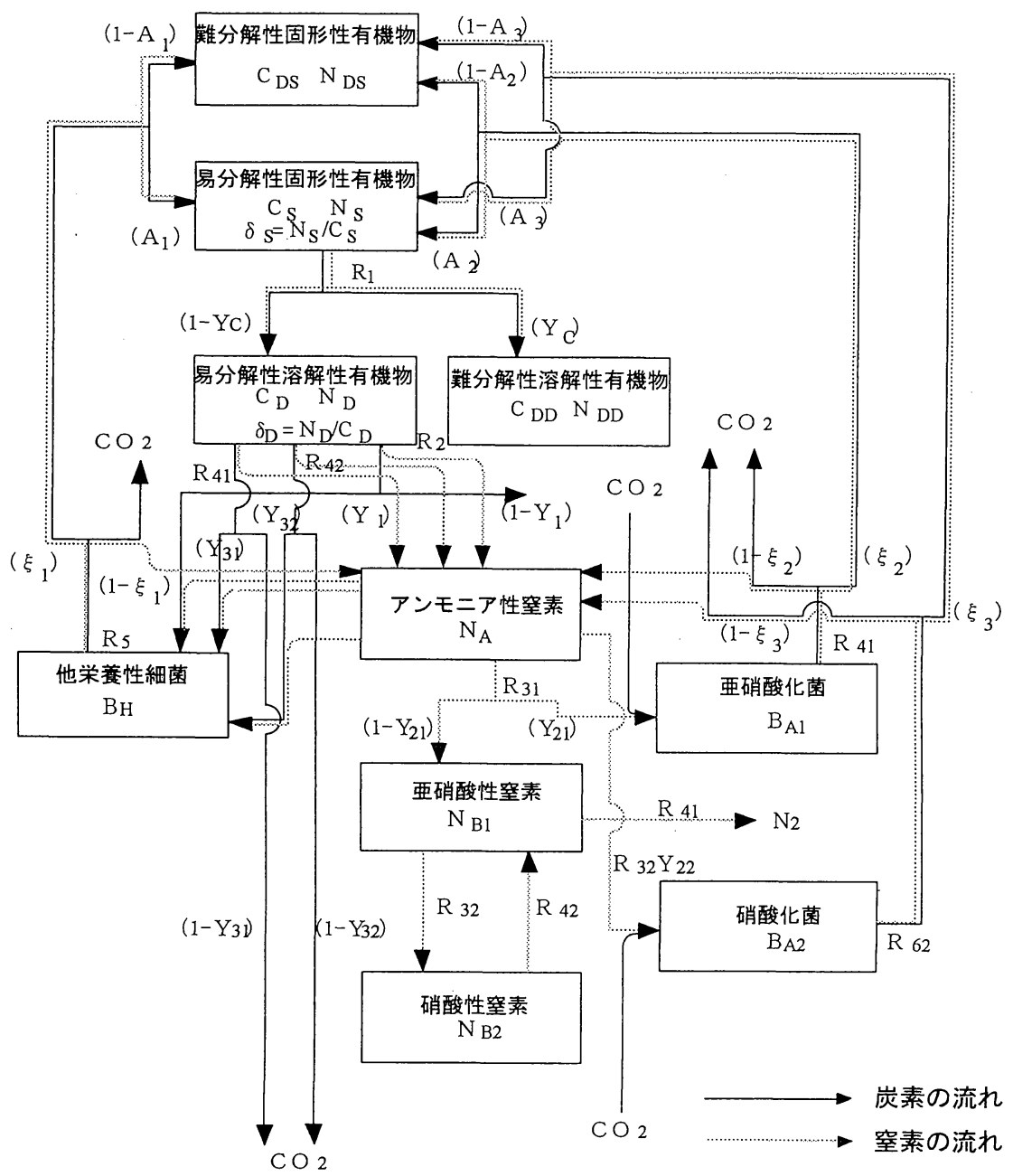

図一2 物質変換モデル概念図

$Q_{30}=Q_{2}+Q_{5}$

ここで， $Q_{k}$ は図-1 に示される䇢所での水量 $\left(\mathrm{m}^{3} / \mathrm{h}\right)$ であり，各式の右辺の $Q_{k}$ の值は実測される. また，分 離槽からの流出量は $Q_{1}$ となる.

反応槽の各区画および分離槽 $j$ (図一1参照) での状 態変数 $i$ の濃度 $C_{i, j}$ の時間的変動は, 各区画や分離槽で の物質収支式により示される，それらの収支式は，反応 器の区画 $j$ での状態変数 $i$ に関わる生成速度を $F_{i, j}$ と し, また分離槽では変換反応は生じないと仮定すると表 -1に示されるようになる.

\section{（2）反応機構のモデル}

生物反応槽で生じている主な機構を組み込んだ反応機 構モデルを作成した. 図一2に物質変換モデルの概念図 を示す. 状態変数として, 亜硝酸化菌 $\left(B_{A 1}\right)$, 硝酸化 菌 $\left(B_{A 2}\right)$, 他栄養性細菌 $\left(B_{H}\right)$, 難分解性固形性有機物 （炭素 $C_{D S}$, 窒素 $N_{D S}$ ), 易分解性固形性有機物（炭素 $C_{S}$, 窒素 $N_{S}$ ), 難分解性溶解性有機物（炭素 $C_{D D}$, 窒
素 $N_{D D}$ ), 易分解性溶解性有機物（炭素 $C_{D}$, 窒素 $N_{D}$ ), アンモニア性窒素 $\left(N_{A}\right)$, 亜硝酸性窒素 $\left(N_{B 1}\right)$, および 硝酸性窒素 $\left(N_{B 2}\right)$ を設定した。なお，アルカリ度は反 応器中で常時 $500 \mathrm{mg} / l$ 前後で存在していたので十分あ ると仮定した．また溶存酸素は制御因子として与えるこ ととした。

モデルに含まれる各状態変数の変換過程は, 易分解性 固形性有機物質の易分解性および難分解性の溶解性有機 物への可溶化, 易分解性溶解性物質の無機化 (アンモ二 ア性窒素の生成) と他栄養性細菌の増殖, アンモ二ア性 窒素の亜硝酸化と亜硝酸化菌の増殖, 亜硝酸性窒素の硝 酸化亡硝酸化菌の増殖, 硝酸性窒素の亜硝酸性窒素への 還元および亜硝酸性窒素の脱窒とこれらの還元に伴う有 機物除去および他栄養性細菌の増殖, ならびに各細菌の. 易分解性および難分解性の固形性有機物への自己分解で ある。

反応速度の数式表現に当たっては, 関与する基質など 
表一2 関与する反応過程とその変化速度の数式表現

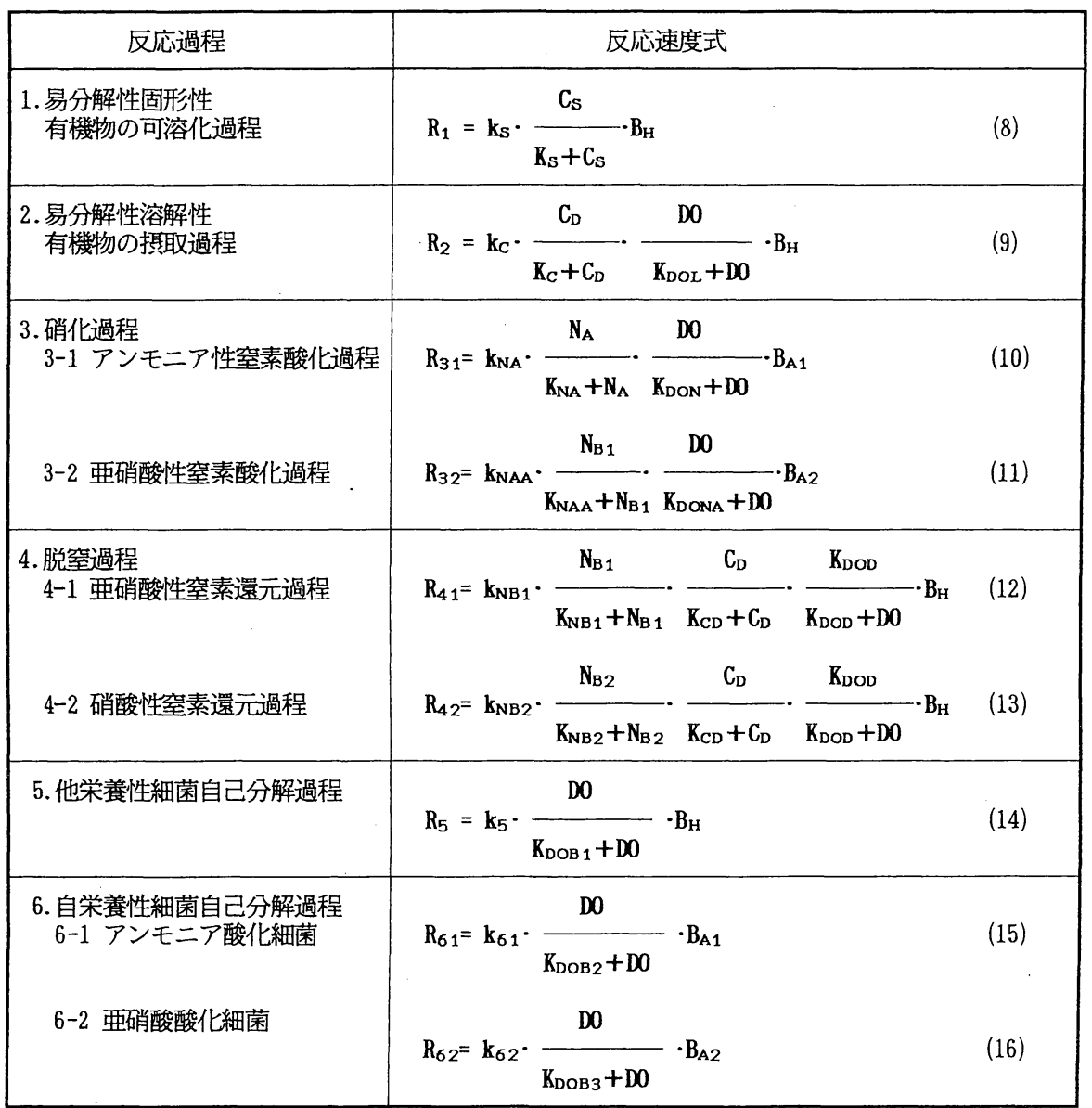

の影響が，半飽和定数 (Michaelis 定数) の値によって 0 次反応から 1 次反応までを表示でき，換算係数の簡略 化ができ，また速度がマイナスとなることを防止しうる ので, Michaelis-Menten 型 (以下 M-M 型と略記する) で表示することとした．易分解性固形性有機物質の可溶 化速度 $\left(R_{1} \mathrm{mg} \mathrm{COD} /(l \cdot \mathrm{h})\right)$ はその濃度に $\mathrm{M}-\mathrm{M}$ 型で 関与し他栄養性細菌濃度に比例するとし，易分解性溶解 性物質の無機化（摂取）速度 $\left(\boldsymbol{R}_{2} \mathrm{mg} \mathrm{COD} /(\boldsymbol{l} \cdot \mathrm{h})\right)$ は その濃度および溶存酸素濃度の影響を $\mathrm{M}-\mathrm{M}$ 型で受け他 栄養性細菌濃度に比例するとして表示した.アンモニア 性窒素の亜硝酸化速度 $\left(R_{31} \mathrm{mgN} /(\boldsymbol{l} \cdot \mathrm{h})\right)$ はその濃度お よび溶存酸素濃度の影響を $\mathrm{M}-\mathrm{M}$ 型で受け亜硝酸化細菌 濃度に比例するとし，亜硝酸性窒素の硝酸化速度 $\left(R_{32}\right.$ $\mathrm{mg} \mathrm{N} /(l \cdot h))$ はその濃度および溶存酸素濃度の影響を $\mathrm{M}-\mathrm{M}$ 型で受け硝酸化細菌濃度に比例するとして表示し た．亜硝酸性窒素の脱窒および硝酸性窒素の亜硝酸性窒 素への還元の速度 $\left(R_{41}, R_{42} \mathrm{mg} \mathrm{N} /(l \cdot \mathrm{h})\right)$ は各々亜硝 酸性窒素あるいは硝酸性窒素の濃度および有機物濃度に $\mathrm{M}-\mathrm{M}$ 型で影響を受けるとし，溶存酸素の影響は飽和型
の阻害関数で表示しうるとし，また他栄養性細菌濃度に 比例するとして式示した．そして各細菌の固形性有機物 への自己分解速度 $\left(R_{5}, R_{61}, R_{62} \mathrm{mg} \mathrm{COD} /(l \cdot \mathrm{h})\right)$ は, 各々の細菌濃度に関して一次で，また溶存酸素濃度に M-M 型で影響を受けるとした。 各過程の変化速度の数 式表現を表一2に示し，また表一3に使用した諸係数の 説明之文献等より得られたそれらの值を示す ${ }^{4) ~ 8)}$. これ らの値は, 硝化に関する半飽和定数の値以外は下水処理 の分野で知られている値である.

各区画 $j$ での各状態変数 $i$ の生成速度 $F_{i, j}$ は, 図一2 に示される関連する速度に収率, 変換割合を乗じたもの の加算で示されるが，その 1 部を表一4に示す.

\section{4. 調査内容}

作成した数理モデルの妥当性を検証するために，流動 特性および処理特性に関する実処理施設調査を行った.

流動調査では，トレーサ物質として溶解性（ $W_{1}=1$, $\left.W_{2}=1\right)$ で保存性 $\left(F_{i, j}=0\right)$ の塩化リチウムを用い, そ の濃度の $\delta$ 応答解析を試みた. すなわち塩化リチウム 5 
表一3 諸係数一覧表

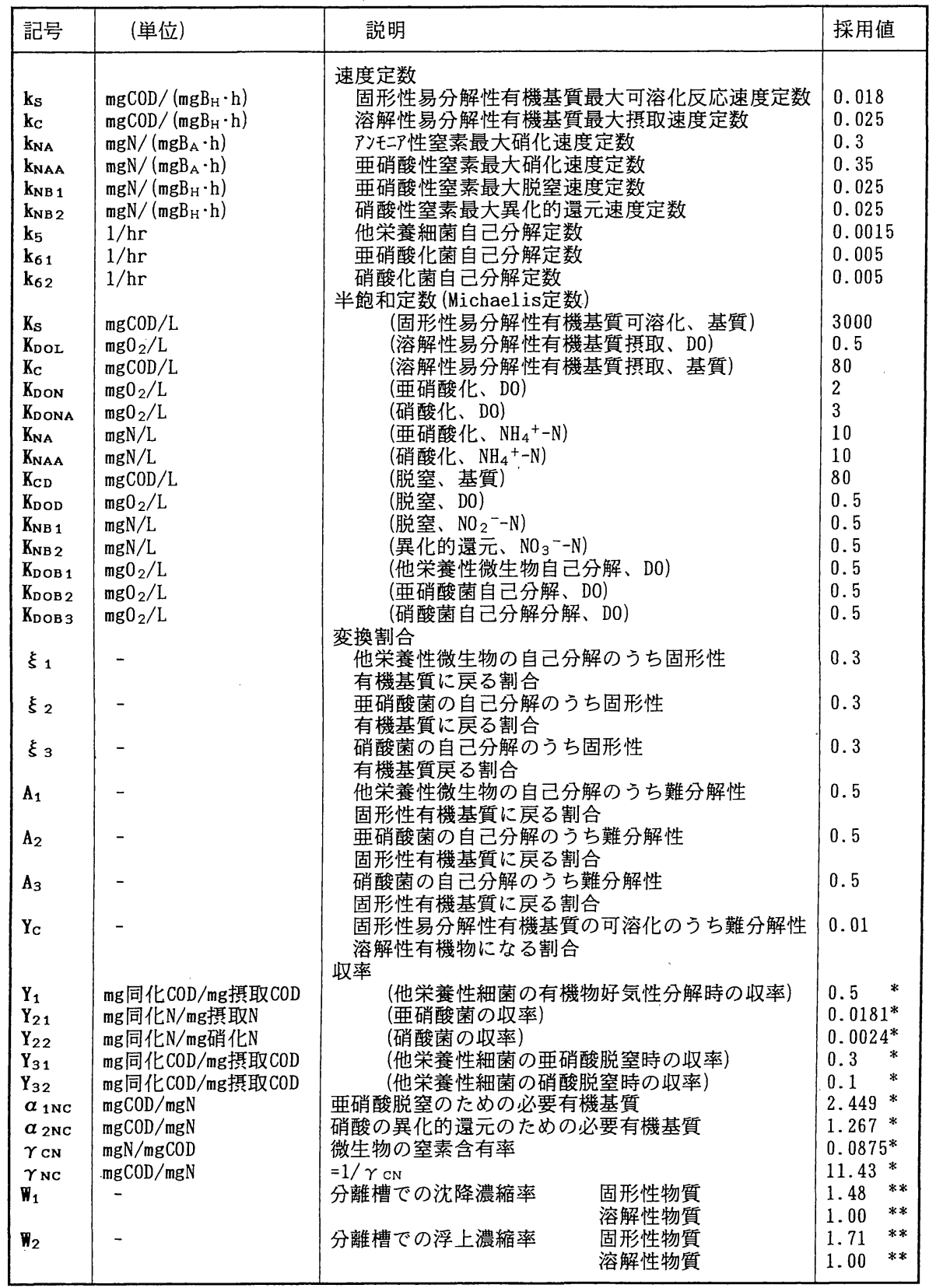

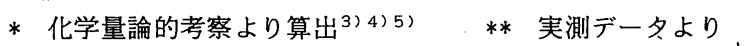

表一4 各状態変数の生成速度式の表示例

\begin{tabular}{|c|c|c|}
\hline $\begin{array}{l}\text { 易分解性溶解性 } \\
\text { 有機物 } \quad \mathrm{C}_{\mathrm{D}, \mathrm{j}}\end{array}$ & $\mathrm{F}_{\mathrm{CD}, j}=\mathrm{R}_{1, j}\left(1-\mathrm{Y}_{\mathrm{c}}\right)-\mathrm{R}_{2, j}-\mathrm{R}_{41, j} \alpha_{1 \mathrm{NC}}-\mathrm{R}_{42, j} \alpha_{2 \mathrm{NC}}$ & (17) \\
\hline アソモニア性窒素 $\mathrm{N}_{\mathrm{A}, \mathrm{j}}$ & 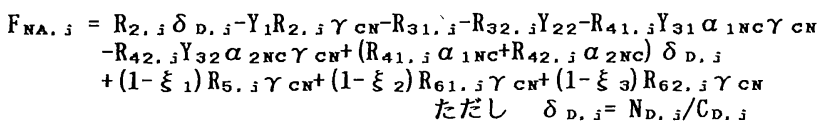 & (18) \\
\hline 亜硝酸性窒素 $\mathrm{N}_{\mathrm{B} 1, \mathrm{j}}$ & $\mathrm{F}_{\mathrm{NB} 1, j}=\mathrm{R}_{31, j}\left(1-\mathrm{Y}_{21}\right)-\mathrm{R}_{41, j}+\mathrm{R}_{42 . j}-\mathrm{R}_{32 . j}$ & (19) \\
\hline 他栄養性細菌 $\mathrm{B}_{\mathrm{H} .}$ s & $\mathrm{F}_{\mathrm{BH}, j}=\mathrm{R}_{2, j} \mathrm{Y}_{1}+\mathrm{R}_{41, j} \mathrm{Y}_{31} \alpha_{1 \mathrm{NC}}+\mathrm{R}_{42, j} \mathrm{Y}_{32} \alpha_{2 \mathrm{NC}}-\mathrm{R}_{5, j}$ & (20) \\
\hline
\end{tabular}




\begin{tabular}{|c|c|c|c|c|c|c|c|}
\hline \multirow{3}{*}{ 項目 } & \multirow{3}{*}{ 単位 } & \multicolumn{3}{|c|}{ 流入水中濃度 } & \multicolumn{3}{|c|}{ 反応槽中濃度 } \\
\hline & & \multicolumn{2}{|c|}{ 実測值 } & \multirow{2}{*}{$\begin{array}{l}\text { 計算 } \\
\text { 使用値 }\end{array}$} & \multicolumn{2}{|c|}{ 実測値 } & \multirow{2}{*}{$\begin{array}{c}\text { 計算值 }{ }^{\mathrm{A})} \\
\mathrm{D} 0=(0.5 、 1)^{\mathrm{B})}\end{array}$} \\
\hline & & 平均値 & 標潐偏差 & & 平均値： & 標準偏差 & \\
\hline アンモニア性窒素 & $\mathrm{mgN} / \mathrm{L}$ & 2700 & 140 & 2700 & 35.6 & 8.0 & $29.8 \sim 48.4$ \\
\hline 酸化態窒素 & $\mathrm{mgN} / \mathrm{L}$ & 0.05 & 0.1 & 0 & 0.2 & 0.1 & $0.23 \sim 0.24$ \\
\hline 溶解性窒素 & $\mathrm{mgN} / \mathrm{L}$ & $3180^{\mathrm{D})}$ & 140 & 3180 & 129 & 39 & $73.1 \sim 94.9$ \\
\hline 全窒素 & $\mathrm{mgN} / \mathrm{L}$ & $3920^{\mathrm{D})}$ & 165 & 3920 & 810 & 157 & $1014 \sim 1037$ \\
\hline 易分解性溶解性 $\mathrm{COD}_{\mathrm{Cr}}{ }^{\mathrm{C}} \mathrm{C}$ & $\mathrm{mg} / \mathrm{L}$ & 5230 & 220 & 5230 & 150 & 21 & $141 \sim 178$ \\
\hline 溶解性 $\mathrm{COD} \mathrm{D}_{\mathrm{Cr}}$ & $\mathrm{mg} / \mathrm{L}$ & 5530 & 520 & 5530 & 570 & 64 & $509 \sim 545$ \\
\hline 固形性COD $\mathrm{Cr}$ & $\mathrm{mg} / \mathrm{L}$ & 9920 & 1860 & 9920 & 9850 & 1700 & $11200 \sim 11300$ \\
\hline
\end{tabular}

注)…A）計算結果の幅は運転1州侁間での最大・最小値を示す

B） DOの表示は、(区画2 $\left(\mathrm{mgO}_{2} / \mathrm{L}\right)$ 、区画 $\left.3\left(\mathrm{mg}_{2} / \mathrm{L}\right)\right)$ とした。 なお区画 1 のDOは、0 $\left(\mathrm{mgO}_{2} / \mathrm{L}\right)$ とした。

C）溶解性BODの測定値に1.43を乗じて算出した。

D）アンモニア性窒素濃度に溶解性の有機性窒素分を加算、またそれに固形性窒素分を加算した檤。

表一6 生物反応槽-分離槽で の有機物および窒素の 除去率

\begin{tabular}{|c|c|}
\hline 項目 & 除去率 (\%) \\
\hline SS & 30.2 \\
\hline VSS & 36.2 \\
\hline TN & 78.3 \\
\hline SN & 94.2 \\
\hline PN & 23.1 \\
\hline $\mathrm{NH}_{4}{ }^{+}-\mathrm{N}$ & 98.4 \\
\hline $\mathrm{T}-\mathrm{COD} \mathrm{D}_{\mathrm{Cr}}$ & 46.4 \\
\hline$S-C O D_{C x}$ & 89.9 \\
\hline $\mathrm{P}-\mathrm{COD}_{\mathrm{Cr}}$ & 22.2 \\
\hline$T-B O D$ & 64.6 \\
\hline S-BOD & 97.6 \\
\hline P-BOD & 32.9 \\
\hline
\end{tabular}

$\mathrm{kg}$ を水道水 $10 l$ に溶解したもの（反応槽での想定濃度 $3 \mathrm{mg} / l$ ) を反応槽 (分離槽を共有している二つの反応槽) の頂部より瞬間的に投入し，各反応槽および分離槽への 流入および流出地点で, 反応槽の水理学的滞留時間の 2 倍に相当する 9 日間にわたり経時的に採水を行い塩化り チウムの濃度変化を追跡した. 塩化リチウム濃度は, 採 水直後にNo. 5 A のろ紙でろ過を行い，そのろ液を対象 に, 原子吸光・フレーム分光光度計により測定を行った.

処理特性調査では, トレーサ濃度分析の試料採水に合 わせて, 反応槽の水理学的滞留時間にほぼ相当する初期 の 4 日間にわたり, 反応槽および分離槽周りの各地点で 採水を行い, 有機物および窒素の物質変換特性を調べた. 測定項目は，溶存酸素， pH，アルカリ度，全および溶 解性の $\mathrm{COD}$ cr , 溶解性 BOD, 全および溶解性の窒素, 溶解性の酸化態窒素, アンモニア性窒素, VSSなどで ある. 分析は下水試験方法 ${ }^{9}$ およびSTANDARD METHODS $^{10)}$ に準拠して行った.

反応槽へのし尿等の流入は，前述のように 1 時間をサ イクルとする間欠流入でなされている.この1サイクル 中での反応槽内での水質変換特性を把握する目的の調査 も併せ行った．この調査では流入開始直後より 10 分毎 に採水を行い，各水質項目について分析を行った．採水 は, 反応槽の区画 1,2 および 3 に相当する 3 つの採水 口より行い, 反応槽の水深方向による水質の違いも把握 した. また同時に反応槽上部よりDOメーターを吊り 下げ，水深 $2 \mathrm{~m}$ の位置における DO も測定した.

\section{5. モデルの検証}

\section{（1） 流動特性}

式（1）加ら（7）および初期条件（ $t=0$ のとき $C_{i, 1}$ $=C_{i, 2}=C_{i, 3}=$ 測定值, $\left.C_{i, 4}=0\right)$ を用いて, $Q_{1}, Q_{2}, Q_{5}$ および $Q_{6}$ の操作值を入力し, 計算したシミュレーショ ン結果 (曲線) を, 塩化リチウムを用いたトレーサ実験

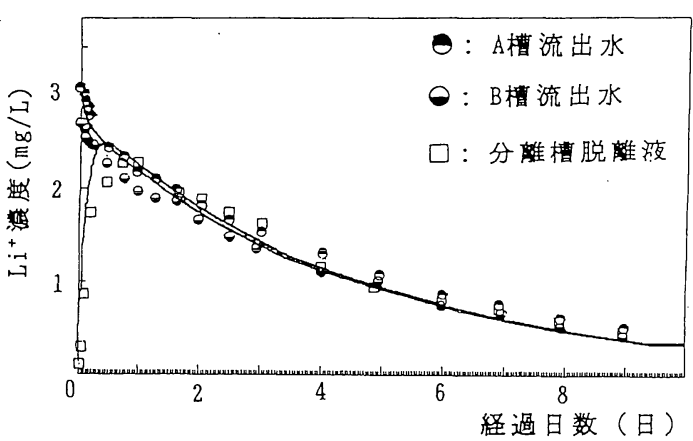

図一3 シミュレーション結果および実測值

での実測值（プロット）とともに図一3に示す，反応槽 および分離槽ともシミュレーション結果と実測值は，濃 度的にも応答特性でもよく合致しており，上記のモデル の水流モデルで実際の状態をシミュレートしうると判断 される. また, 生物反応槽は完全混合の 3 区画に分割し たモデルであるが，底部より頂部への大量の混合液の循 環により，流動調查で示されているような，1槽の完全 混合槽と同様の流動状況が現出されている.

\section{（2）処理特性}

本調査に基づく, 各水質項目の流入水中および反応槽 流出水中の濃度の実測値 (平均値), ならびに生物反応 槽・分離槽での除去率を表一 5 および表一 6 にまとめて 示す. 反応槽内のアルカリ度は平均 500 (標準偏差 35) $\mathrm{mg} / \mathrm{l}$ で, $\mathrm{pH}$ は 6.9 であり,この観点での変換速度への 影響は小さいものと判断される。溶存酸素濃度は区画 2 で $0.5 \mathrm{mg} / l$ 程度であった. 流入水中の全窒素は 3920 $\mathrm{mg} / l$ および全 $\mathrm{COD}_{\mathrm{Cr}}$ は $15500 \mathrm{mg} / l$ 程度であり, また アンモニア性窒素および溶解性 COD $\mathrm{Cr}$ は各々 2700 お よび $5530 \mathrm{mg} / l$ 程度であった. 生物反応槽・分離槽で 固形物関連は $20 \sim 35 \%$ 程度除去され, 溶解性関連は $80 \%$ 以上除去されている. とくに, 溶解性窒素や溶解 性 BOD は $95 \%$ 程度除去され，各々 130 および 100 


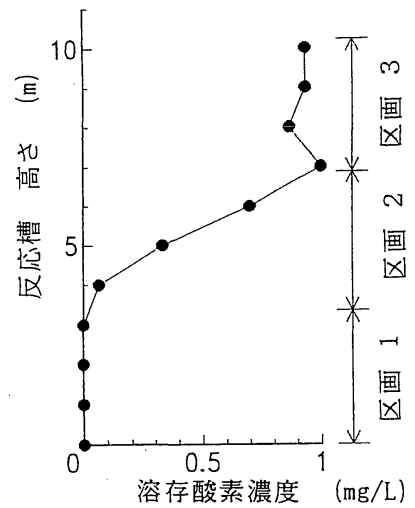

図一4 反応槽内の DO 濃度分布

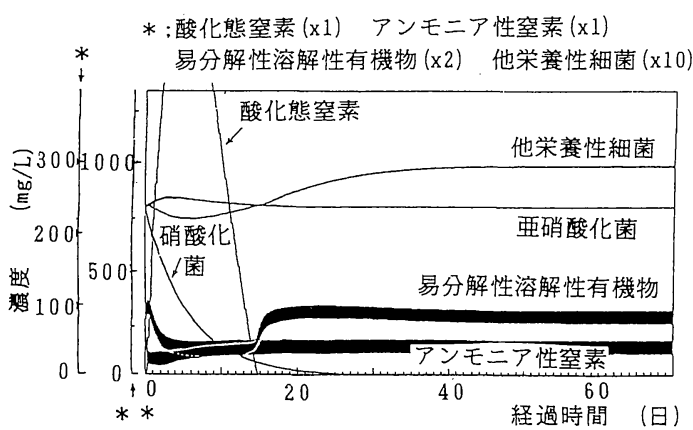

図一5 定常状態に達するまでのシミュレーション結果例 **; 亜硝酸化菌 硝酸化菌

$\mathrm{mg} / l$ 程度となっており，良好な処理がなされていたと 判断される. また, 溶存酸素や ORP 以外の水質項目は, 上述の流動特性によって, 反応槽の上部加ら底部にいた るまでほとんど濃度差はなく，各水質変換反応で必要な 有機物やアルカリ度の供給・消費が本反応槽では有効に なされている，なお，固形物質に関しては，分離槽の後 に脱水処理がなされ，ほとんどの固形物質が除去される システムであり問題はない.

作成したモデルでこれらの処理状況をシミュレートし うるか検討を試みた．表一5に示される流入水質，槽の 各区画の容積（この計算では, 反応槽 1 つに分離槽 1 つ を対応させるとして分離槽の容積は $30 \mathrm{~m}^{3}$ とした), 操 作水量, および操作条件下での溶存酸素濃度（反応槽区 画 1 では $0 \mathrm{mg} / l$, 区画 2 および区画 3 では各々 0.5 お よび $1 \mathrm{mg} / l$ : 図一 4 に溶存酸素濃度分布の実測值を示 す）を入力し定常状態になるまで計算を行った。ここで の定常状態とは，し尿等の投入サイクル内での変動は生 ずるが，各サイクル間で変動状態が同一になった状態を 示す．この例を図一 5 に示す．この図では，現在とられ ている操作条件下ではSRTは 6 日程度であり，硝酸化 菌は系から流亡し亜硝酸化菌のみが残存し，脱窒は亜硝 酸脱窒が卓越することも示されている．亜硝酸脱窒が生

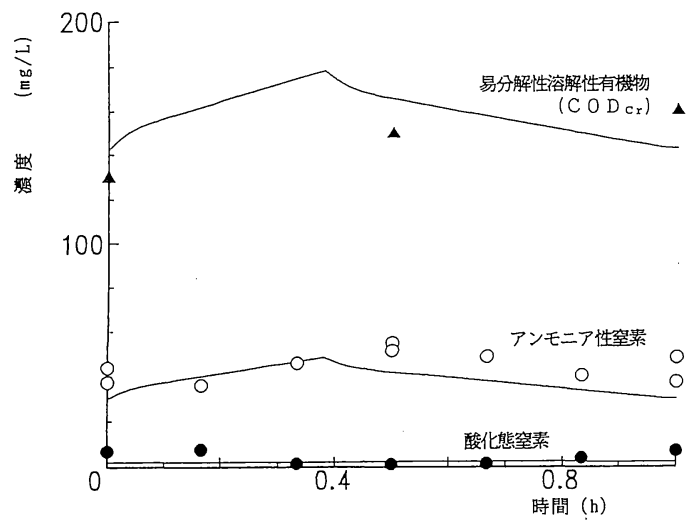

図一6 1 サイクル $(1 \mathrm{hr})$ におけるシミュレーション結果 (曲線) と実測值 (プロット)

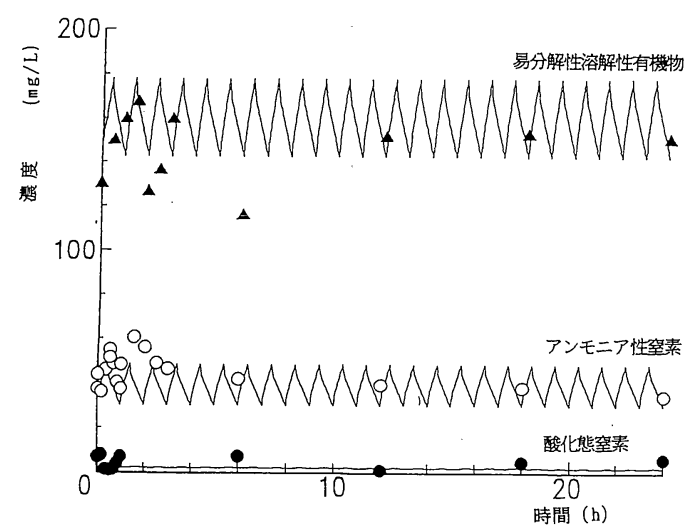

図一71日におけるシミュレーション結果 (曲線) と実測值 (プ ロット)

ずるとすると, 窒素 $1 \mathrm{mg}$ 当り脱窒するのに必要な有機 物量は微生物の増殖も考虑に入れる（収率を COD ゙ー一 スで 0.3 とする）と $1.71 / 0.7=2.45 \mathrm{mg} \mathrm{COD} \mathrm{Cr}_{\mathrm{r}}$ である. したがって, 流入水中のアンモニア性窒素 $2700 \mathrm{mg} / l$ を硝化・脱窒するのに必要な有機物濃度は概算で 6600 $\mathrm{mg} / l$ となり，これを満たすためには固形性有機物の可 溶化による供給が重要である.

定常状態に達した後での, シミュレーション計算の結 果 (DO 濃度は区画 1 で $0 \mathrm{mg} / l$, 区画 2 で $0.5 \mathrm{mg} / l$ お よび区画 3 で $1 \mathrm{mg} / l$ の条件下） と実測值との比較を表

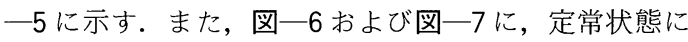
達した後の 1 サイクル $(1 \mathrm{~h})$ および 1 日におけるシミュ レーション結果と，それらに対応する実測値との比較を 示す.これらの結果より，提示したモデルにより実際の 処理状況をサイクル中の変動も含め再現しうると判断さ れる。

\section{6. 操作因子に関する検討}

\section{(1) 溶存酸素}

反応槽の区画 1 での溶存酸素は $0 \mathrm{mg} / l$ に固定し, 区 

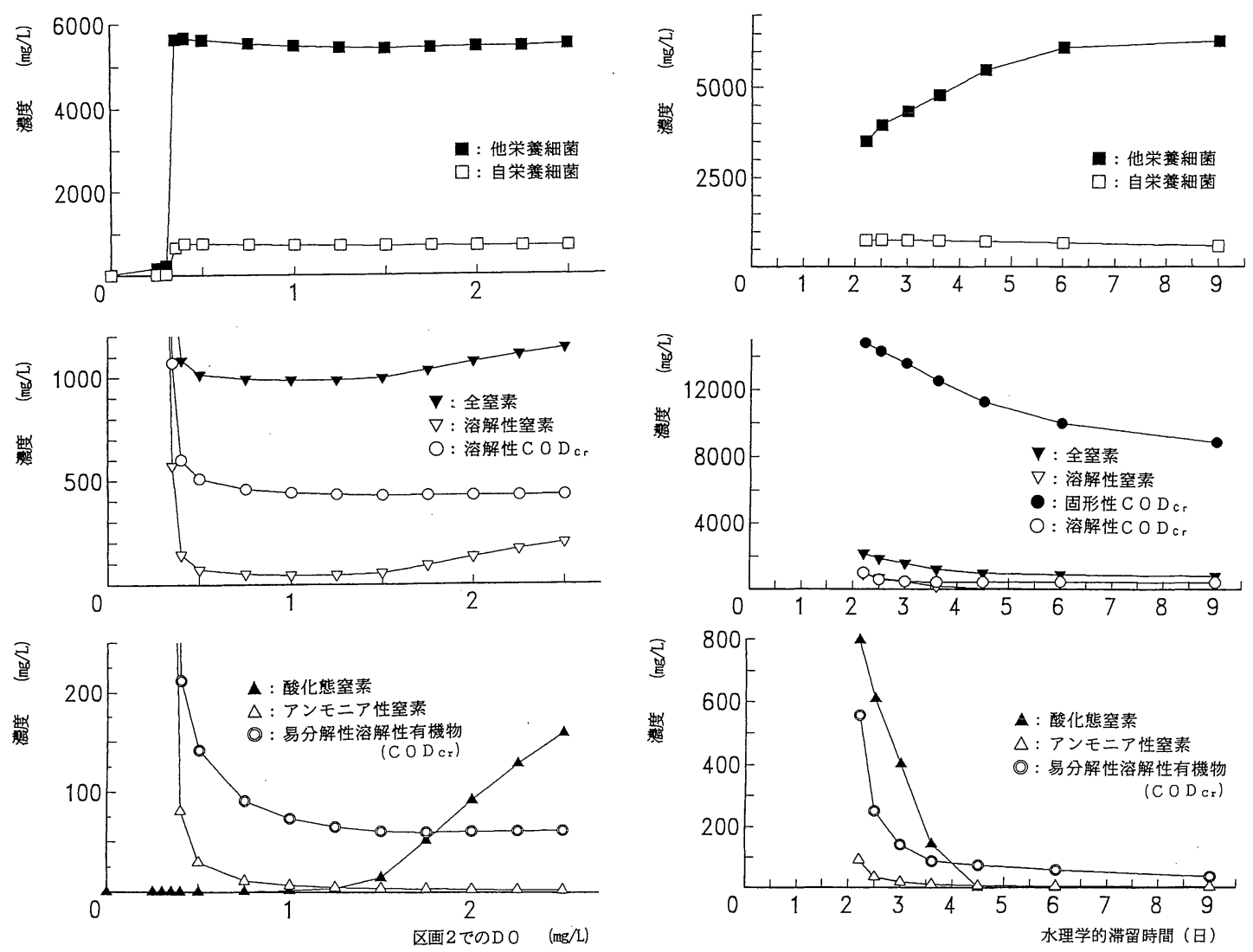

図一8＼cjkstart処理特性に及ぼす溶存酸素濃度の影響

(区画 1 では $0 \mathrm{mg} / l$, 区画 3 では区画 2 での 2 倍の濃度)

画 2 の溶存酸素濃度を種々変えて（区画 3 の溶存酸素濃 度は区画 2 の 2 倍の值とし), 定常状態になるまで計算 し, 溶存酸素濃度の処理特性に及ぼす影響を検討した結 果を図一 8 に示す. この時の反応槽内の水理学的滞留時 間は 4.5 日であり, 現在操作されている条件である. 溶 存酸素濃度を低下させると, 硝化が起こりにくくなり, 酸素呼吸とともに硝酸呼吸の量も減るため他栄養性細菌 および自栄養性細菌も急に減少し系内に保持できなくな る溶存酸素濃度が存在し, それは区画 2 での濃度で 0.3 から $0.4 \mathrm{mg} / l$ 程度（区画 3 での DO濃度は 0.6 から $0.8 \mathrm{mg} / l)$ であることが示されている. また, 区画 2 で の DO 濃度が $1 \mathrm{mg} / l$ (区画 3 での DO 濃度は $2 \mathrm{mg} / l$ ) 程度を境にして, それよりも高くなると酸化態窒素の濃 度が上昇し, それ以下ではアンモニア性窒素の濃度が上 昇する傾向が示されている. また，このDO濃度以下 になると易分解性溶解性 COD の残存濃度が高くなる傾 向も示されている. アンモニア性窒素が上昇するのは, 硝化に必要な酸素量が不足するためである. 一方, DO 濃度が高くなると酸化態窒素濃度が高くなるのは, DO による脱窒の抑制に加え; 有機物の酸素呼吸による消費 と硝酸呼吸による消費とのバランスが崩れ脱窒に必要な

有機物量が不足することも原因となる.

以上より, 現在の操作条件下では, DO 濃度は区画 2 で $1 \mathrm{mg} / l$ (区画 3 での DO 濃度は $2 \mathrm{mg} / l$ ) 程度で運転 されることが処理性からも, その安定性からも適切であ ると判断される. また, この值を中心にして, DO 濃度 は区画 2 で $0.5 \sim 1.5 \mathrm{mg} / l$ (区画 3 での DO 濃度は $1 \sim 3$ $\mathrm{mg} / l)$ 程度で運転されると安定した処理が得られると 判断される.

\section{（2）水理学的滞留時間}

今までの検討は, 現状の操作条件である反応槽内の水 理学的滞留時間が 4.5 日での検討である. 水理学的帯留 時間を種々変えて定常状態になるまでシミュレーション 計算を行い, 水理学的滞留時間が処理特性に及ぼす影響 について検討した結果を図一-9に示す。この図はDO 濃 度が区画 2 で $1 \mathrm{mg} / l$ (区画 3 での DO 濃度は $2 \mathrm{mg} / l$ ) の操作条件のものである. 水理学的滞留時間が 2 日より 大きければ, 硝化に関与する自栄養性細菌の反応槽内の 現存量はあまり変化しないが, 有機物分解や脱窒に関与 する他栄養性細菌の反応槽内の現存量は水理学的滞留時 間が 6 日以下では小さくなるにつれて減少する傾向が示 されている. 反応槽内 (=反応槽流出水中) の易分解性 


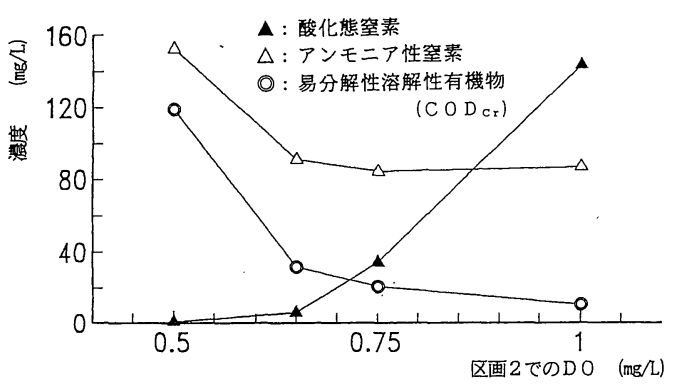

図一10 処理特性に及ぼす溶存酸素濃度の影響 $(\mathrm{HRT}=3.6$ 日）

の溶解性有機物の濃度は, 水理学的帯留時間が 3 日より 小さくなると急激に上昇する傾向が示されている. また 酸化態窒素濃度は水理学的滞留時間が 4.5 日より小さく なると上昇し始め 3.6 日以下になると急激に上昇する傾 向が, そしてアンモニア性窒素濃度は水理学的滞留時間 が 3 日以下になると上昇する傾向が示されている. 全窒 素および溶解性窒素は, 水理学的滞留時間が 3.6 日以 下になると, また溶解性 COD の濃度は 2.5 日以下にな る上上昇する傾向がみられる. 以上より, 水理学的滞留 時間は 4.5 日であれば安定した処理が得られると判断さ れる. なお, 水理学的滞留時間を 3.6 日に設定しても良 好な処理が得られる可能性が示唆されている.

水理学的滞留時間を 3.6 日とした処理状況を図一9に より検討すると, アンモニア性窒素の除去は良好である が, 酸化態窒素および易分解性溶解性 COD の除去が劣 ることが分かる.このため, 水理学的滞留時間を 3.6 日 に設定して, 操作 DO 濃度を種々変えて計算を行い, それが処理特性に及ぼす影響を検討した結果をに図一-10 に示す. 区画 2 での DO が $0.65 \mathrm{mg} / l$ 以上であれば, 易分解性溶解性 COD およびアンモニア性窒素の除去は 良好であるが, 酸化態窒素の濃度が上昇し始める傾向が 見られる.これらより，区画2でのDOを0.65〜0.7 $\mathrm{mg} / l$ 程度に設定すれば, 水理学的滞留時間 4.5 日と同 等の処理成績が得られることが分かる. しかしながら, 図一8 と図一10 との比較より明らかなように，水理学的 滞留時間 3.6 日の操作では良好な処理の得られる DO 条件の幅が極端に小さく, 安定した処理を余裕を持って 得るためには 4.5 日の水理学的滞留時間が望ましいと判 断される.

\section{7. 結語}

本研究では, 単一槽高負荷脱窒素反応器による有機物 および窒素の除去機構のモデル化を試みるとともに，そ の数理モデルを用いて操作因子の検討を試みた. 本研究 で得られた主な成果は以下のとおりである.

（1）流動モデルでは反応槽を好気性ゾーン, 微好気 性ゾーンおよび無酸素ゾーンを設定しうるように三つの
区画に分割したが，このモデルにより流動状態を十分に 表示し得ることが塩化リチウムをトレーサに用いた流動 調査で検証された。

（2）有機物除去, 硝化, 脱窒および関連微生物の増 殖の各過程を組み込んだ物質変換モデルと流動モデルを 結合して, 処理特性を表示しうる数理モデルを作成した. このモデルは, 下水処理で知られる速度定数などの值を 用いることにより, 処理特性を再現しうることが, 長期 間調査の平均值, 一日のデータおよび操作 1 サイクルの データとの比較により検証された。

（3）このモデルを用いて, 操作因子である溶存酸素 濃度と水理学的滞留時間の影響を検討した. 反応槽内の 水理学的滞留時間が 4.5 日の場合では, 中層での DO 濃度は $1 \mathrm{mg} / l$ 程度で運転されることが処理性からも, その安定性からも適切であり, また, $0.5 \sim 1.5 \mathrm{mg} / l$ 程 度で運転されると安定した処理が得られると判断され る.

（4）水理学的滞留時間を 3.6 日に設定しても良好な 処理が得られる可能性が示唆される. しかしながら, 水 理学的滞留時間 3.6 日の操作では安定操作の DO 条件 の幅が極端に小さく (中層での DOを $0.65 \sim 0.7 \mathrm{mg} / l$ 程度に設定する必要があり), 安定した処理を余裕を持っ て行うためには 4.5 日の水理学的滞留時間が望ましいと 判断される.

\section{参 考 文 献}

1）中西 弘：し尿処理の進展：水質污濁研究, Vol.14, No. 11, pp. 767 771, 1991.

2）桜井敏郎：し尿の高負荷生物処理技術：水質污濁研究, Vol.14, No.11, pp. 772 776, 1991.

3) IAWPRC : Activated sludge model No.1; Scientific and technical reports No.1, 1986.

4）宗宮 功・津野 洋 - 野村和弘 - 笹井晋一：活性污泥法 における有機物除去および硝化特性の動力学モデル化に 関する研究, 下水道協会誌, Vol.27, No. 316, 論文集, No. 1, pp. 23 33, 1990.

5) U.S. EPA : Process design manual for nitrogen control, 1975.

6) 宗宮 功: 生物学的脱窒, 微生物による環境制御 - 管理 技術マニュアル，環境技術研究会，pp. 263２68，1983.

7）日本下水道事業団技術評価委員会：微生物を利用した窒 素及びリン除去プロセスの評価に関する第 1 次報告書, 1986.

8）保田雄二：膜分離を適用した污水処理プロセスの設計・ 操作因子に関する研究, 京都大学博士学位論文, 1994 .

9）日本下水道協会：下水試験方法、1984.

10) APHA, AWWA, WPCF : STANDARD METHODS, 16 th EDITION, 1985.

(1993.7.14 受付) 


\section{MODELING AND OPERATION PARAMETERS FOR SINGLE HIGH-LOADED DENITRIFICATION REACTOR}

Hiroshi TSUNO, Isao SOMIYA, Toshio YAMADA and Fumitake NISHIMURA

Single high-loaded denitrification reactor has been developed and applied to treatment of night soil. Degradation of organic compounds, nitrification and denitrification occur concurrently in the reactor by the creation of both aerobic and anoxic zones and circulation of mixed liquor. In this study, a mathematical model is developed, in which the reactor consists of 3 zones ( 2 are aerobic and 1 is anoxic) and degradation of organics, nitrification, denitrification and growth of bacteria associated with each process are incorporated. The model is verified by the comparison of the simulated results with the tracer experiment and the performance results of the reactor operated in practice to treat night soil. The optimum operational conditions of the reactor for night soil treatment is discussed by the model. It is shown that the hydraulic retention time of 4.5 days in the reactor and DO concentration of $1 \mathrm{mg} / l$ in the middle zone between anoxic zone and higher DO zone are optimum for both fine and stable treatment. 